\title{
Do Anti-dumping Duties Still Matter? The Curious Case of Aluminum Foil
}

\author{
SHUSHANIK HAKOBYAN * \\ International Monetary Fund
}

\begin{abstract}
In 2009, the EU imposed anti-dumping duties on aluminum foil imported from Armenia, Brazil, and China for five years. The final determination resulted in the imposition of definitive anti-dumping duties of $13.4 \%$ (Armenia), $17.6 \%$ (Brazil), and $6.4-30 \%$ (China). This paper quantifies the direct and indirect effects of the EU anti-dumping duty on EU and US imports from targeted and unaffected countries using detailed data for the years 2006 through 2012, and controlling for exports of all products within the aluminum sheet, plate, and foil manufacturing industry from all countries. The findings point to the trade destruction, trade depression, trade diversion, and trade deflection effects typically found in the existing literature. However, the uniqueness of this case lies in the fact that the Armenian exporter is a subsidiary of a Russian firm. And as Armenia's exports to the EU declined, they expanded rapidly to the US. At the same time, the US imports from Russia, a country not directly touched by the anti-dumping ruling, declined dramatically, and were diverted to the EU. This points to the potential ineffectiveness of anti-dumping duties in the presence of multinational corporations with production facilities located across countries differentially impacted by anti-dumping duties.
\end{abstract}

\section{Introduction}

In an attempt to protect the domestic aluminum foil industry of some of its member countries, the EU imposed anti-dumping (AD) duties on aluminum foil imported from Armenia, Brazil, and China in 2009 for a period of five years. The final duties ranged from $6.4 \%$ to $30 \%$ depending on country and exporting firm.

A priori, the EU-imposed anti-dumping duties should have resulted in reduced imports from the targeted countries. Such an outcome, which is observed in EU trade statistics, should not come as a surprise. A related question of interest is whether the anti-dumping duties had any other indirect effects on trade in aluminum foil. In particular, were exports from the targeted countries diverted to the

\footnotetext{
*Email: shakobyan@imf.org. The views expressed in this paper are those of the author and do not necessarily represent the views of the IMF, its Executive Board, or IMF management.
} 
US, the next largest destination market for aluminum foil? ${ }^{1}$ Did the exports from unaffected countries to the EU increase post-ruling to displace those from the targeted countries? The existing literature addresses these questions in a more general setting, whereas this paper offers a very precise and focused case study.

Because the targeted countries vary greatly in country size, stage of development, distance, and production structure and capacity, the response to anti-dumping duties may also vary by country. China, for instance, as the 'world's manufacturing powerhouse' may have the capacity to absorb the duties or switch to producing very close substitute products. The latter point is particularly relevant as the EU levied anti-dumping duties on aluminum foil rolls in excess of $10 \mathrm{~kg}$ in weight, and exempted rolls under $10 \mathrm{~kg}$ in weight.

At the other extreme, Armenia is a small landlocked country with GDP under $\$ 10$ billion, and with aluminum foil virtually representing the only industrial export to the EU, amounting to 15 million euros in 2007, albeit rapidly growing, prior to the anti-dumping investigation. It does not have China's capacity to absorb the duties nor the ability to switch to a close substitute. While it is much closer to Europe than Brazil and China, it is burdened by a closed GeorgianRussian border, which adds to the cost of imported raw materials from Russia, and a closed border with Turkey, which may add to shipping costs. But Armenia is also unique in that the sole producer of aluminum foil, Armenal, is a subsidiary of the Russian producer, Rusal. Intra-firm dynamics may shape Armenia's response to the anti-dumping duties, and provide a glimpse of how multinational corporations may respond to the $\mathrm{AD}$ rulings.

Anti-dumping duties may affect the targeted countries directly and indirectly, as well as alter the exports of other countries. Following Bown and Crowley (2006), these effects may take the form of trade destruction, trade depression, trade diversion, and trade deflection. ${ }^{2}$ In our context, an increase in US imports of aluminum foil from Armenia, Brazil, and China would capture the trade deflection effect, while a decrease in US imports from Russia or any other unaffected country, the trade depression effect. The trade destruction and diversion effects would be represented by a decrease in EU imports of aluminum foil from affected countries and an increase in imports from unaffected countries, respectively.

Figure 1 shows the pattern of US imports of aluminum foil from countries affected by the EU anti-dumping duty as well as that from the rest of the world.

1 According to author's calculations using UN Comtrade data, the US and the EU are the largest importers of aluminum foil products (classified under HS 6-digit product code 760711) worldwide, accounting for over one-third of global imports between 2006 and 2012. The next largest importers (Canada, Switzerland, and Mexico) have shares of much smaller magnitude (e.g. 4-7\% in 2012).

2 Trade destruction is the direct effect of AD duties on imports from affected countries. Trade depression refers to the indirect effect of $\mathrm{AD}$ duties on imports from unaffected countries to the third markets. Trade diversion is the indirect impact of $\mathrm{AD}$ action on imports from unaffected countries into the market of the country imposing the AD duties. Finally, trade deflection is another indirect effect of AD duties whereby affected countries export the named product to a third country. 
Figure 1. US imports of aluminum foil

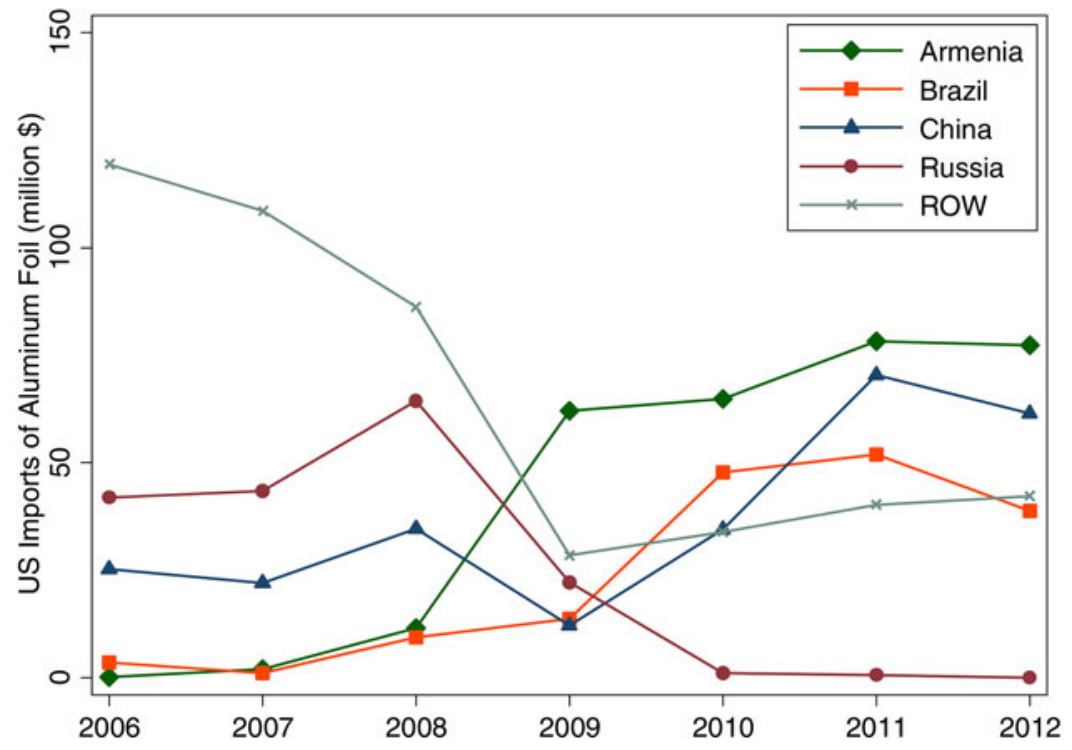

Notes: Data on imports of HS 8-digit product 7607.11.60.

There is a clear break in the data in 2009, the year the EU imposed AD duties which also coincided with the great recession. The dramatic decline in imports of aluminum foil from Russia and rest of the world (trade depression) is accompanied by sharp rises in such imports from the three countries affected by the EU antidumping duties, Armenia, Brazil, and China (trade deflection). Figure 2 further illustrates the potential trade destruction and trade diversion with the imposition of EU anti-dumping duties on imports of aluminum foil from Armenia, Brazil, and China. The decrease in imports from Armenia and Brazil to the EU (trade destruction) coincides with dramatic increase in imports from Russia and rest of the world (trade diversion). There is great variation in imports from China over this period with a dramatic decline in 2009 followed by a quick recovery. ${ }^{3}$

This paper quantifies the effect of EU anti-dumping duties on aluminum foil imported from Armenia, Brazil, and China, captured in Figures 1 and 2. In particular, we estimate how much EU and US imports of aluminum foil from affected and

3 The anti-dumping duty was imposed in the midst of the worst global financial crisis, which depressed the global demand for many commodities. The sharp drop in exports from China to the EU in 2009 possibly captures the effect of suppressed demand for aluminum foil in the EU, and the subsequent rise to pre2009 levels is arguably a return to normalcy after the global financial crisis. Furthermore, the aluminum foil industry is likely characterized by economies of scale, and arguably only Chinese producers had the capacity to expand their production and exports after the imposition of the duty. 
Figure 2. EU imports of aluminum foil

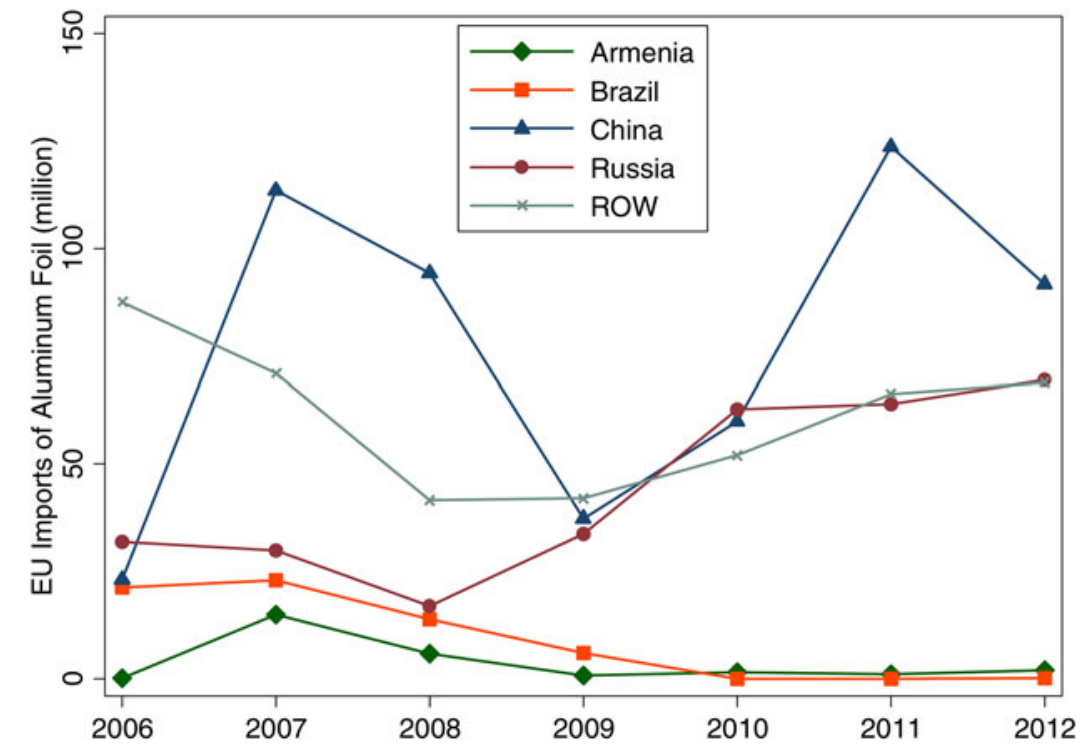

Notes: Data on imports of CN 8-digit product 7607.11.10 for 2006-2008 and combined imports of CN 8digit products 7607.11 .11 (under $10 \mathrm{~kg}$ ) and 7607.11 .19 (over $10 \mathrm{~kg}$ ) for 2009-2012.

unaffected countries have changed due to the EU anti-dumping duties that went into effect in 2009. Because the anti-dumping duties applied selectively to both countries and products, we are able to estimate their impact using triple difference-in-differences (product, country, anti-dumping action).

Employing a detailed dataset on US and EU imports of aluminum products (e.g., sheet, foil, and rod) at the 8-digit HS and CN levels from all countries for the years 2006 through 2012, we find strong evidence of trade deflection (increase in US imports of aluminum foil from affected countries), trade depression and trade diversion (decrease in US imports and increase in EU imports of aluminum foil from unaffected countries, respectively), and trade destruction (decrease in EU imports of aluminum foil from affected countries). In particular, imports from Armenia and Brazil to the EU decreased by $94 \%$ on average after 2009 (from a pre-duty average of about 7 and 19 million euros for Armenia and Brazil, respectively), while simultaneously imports from Russia to the EU increased by $820 \%$ (from a pre-duty average of 26 million euros). These effects are reversed on the US market in that imports from Armenia and Brazil increased by 1,200 and $750 \%$, respectively (from a pre-duty average of $\$ 4.5$ million for both countries), while imports of aluminum foil from Russia declined by $98 \%$ (from a pre-duty average of $\$ 50$ million). We do not find any significant changes in trade patterns between China and EU, as well as China and US, and we attribute this to the potential measurement error in Chinese imports directly affected by the EU AD 
duty. ${ }^{4}$ In case of Armenia and Russia, these findings suggest that with the imposition of anti-dumping duties, Rusal, the Russian exporter, has shifted its exports from its Armenian subsidiary to the next largest destination market, the United States, and continued to supply aluminum foil to the EU market from its Russiabased plants.

The remainder of this paper is organized as follows. Section 2 provides an overview of the EU decree and background leading to the imposition of duties, followed by a brief review of the existing literature. Section 3 reviews trends in exports of aluminum foil to the US and EU, describes data sources, and introduces the empirical specification. Results are reported in Section 4, and concluding remarks are provided in Section 5.

\section{Background}

\subsection{EU Anti-dumping investigation}

Following a complaint lodged by the European Association of Metals (Eurometaux) on behalf of its members, the European Union initiated an antidumping investigation into imports of aluminum foil from Armenia, Brazil, and China in July of 2008.5 The allegedly dumped product was aluminum foil of a thickness of not less than $0.008 \mathrm{~mm}$ and not more than $0.018 \mathrm{~mm}$, not backed, not further worked than rolled, in reels of a width not exceeding $650 \mathrm{~mm}$, normally declared within CN 8-digit product code 7607.11.10. The EU's preliminary investigation was completed in April 2009, and provisional anti-dumping duties were imposed on imports of aluminum foil originating from Armenia (20\%), Brazil $(25.9 \%)$, and China (ranging from $10.7 \%$ to $42.9 \%) .6$ The final determination resulted in the imposition of definitive anti-dumping duties of $13.4 \%$ (Armenia), $17.6 \%$ (Brazil), and 6.4-30\% (China) in September 2009 for five years. ${ }^{7}$ In case of Armenia, the company that produces aluminum foil, Armenal, is the subsidiary of a Russian company Rusal. Yet Russia was not part of the investigation. ${ }^{8}$

4 Due to a split in the subject product code into two separate product codes, the analysis in the paper relies on the combined value of imports of the two products. However, only one of these products is subject to the anti-dumping duty. Hence, the effect of the EU anti-dumping duty may be underestimated due to the mismeasurement of imports targeted by it. This is discussed in more detail below in subsection 2.1.

5 Official Journal of the European Union of 12 July 2008 (OJ 2008 C 177, p. 13).

6 Official Journal of the European Union of 8 April 2009 (OJ 2009 L 94, p. 17).

7 Official Journal of the European Union of 6 October 2009 (OJ 2009 L 262, p. 1). The AD duties were country-wide for Armenia and Brazil at 13.4 and 17.6\%, respectively. For China, the final AD duties are separately specified for four firms: Alcoa (Shanghai) Aluminium Products Co. Ltd and Alcoa (Bohai) Aluminium Industries Co. Ltd (6.4\%), Shandong Loften Aluminium Foil Co. Ltd (20.3\%) and Zhenjiang Dingsheng Aluminium Co. Ltd (24.2\%). For all other Chinese firms the AD rates were set at $30 \%$.

8 Rusal, founded in 2000, is a global aluminum producer and one the world's major producers of alumina: in 2015 , it accounted for approximately $7 \%$ of global production of aluminum and $7 \%$ of alumina. It operates in 13 countries and owns four aluminum foil mills, three in Russia and one in Armenia, producing about 90 thousand tons of foil per year. Armenal, Rusal's subsidiary in Armenia, is 
Armenia and China were treated as non-market economies in this anti-dumping investigation, and, therefore, a third country, Turkey, was used to calculate the production costs of aluminum foil. Armenia became a WTO member in 2003, and the Armenian producer repeatedly insisted on Armenia being considered as a market economy. After the AD duties were imposed, the Armenian producer of aluminum foil lodged a complaint with the General Court of the European Union requesting the annulment of the regulation arguing that the calculation of dumping margins was based on erroneous assumptions. On 5 November 2013, the Court annulled the earlier Council Regulation of September 2009 imposing a definitive antidumping duty on imports of certain aluminum foil originating in Armenia and ordered the EU Council to pay the costs incurred by Armenal in the case. ${ }^{9}$

One complicating factor in assessing the impact of AD duties on EU imports of aluminum foil is the fact that in 2009 the product code subject to the anti-dumping proceeding (CN 8-digit product 7607.11.10) was split into two separate codes to distinguish aluminum foil by weight-under $10 \mathrm{~kg}(\mathrm{CN}$ 8-digit product 7607.11.11) and in excess of $10 \mathrm{~kg}$ (CN 8-digit product 7607.11.19). The initial complaint lodged by Eurometaux targeted high-weight aluminum foil or socalled jumbo reels. In particular, four domestic producers of jumbo reels, two located in Bulgaria and Greece, were directly competing with imports from Armenia, Brazil, and China. ${ }^{10}$ During the investigation, the representatives of the downstream industry (the rewinders who purchase jumbo reels and convert them into low-weight or so-called consumer rolls) warned against a possible substitution effect if consumer rolls are left out of the $\mathrm{AD}$ investigation. The concern raised by the EU domestic rewinders about the possible substitution effect may partly explain the quick rebound in overall imports of Chinese aluminum foil observed in Figure 2. The Council however decided to treat consumer rolls as a different product and not include them in the current investigation. ${ }^{11}$

\subsection{Related literature}

Blonigen and Prusa (2016) provide an extensive survey of the existing literature on the impact of AD duties. Prusa (1997) and Prusa (2001) provide strong evidence of trade destruction and trade diversion by examining US AD actions initiated

the only foil producer in Caucasus and Central Asia, and has been wholly owned by Rusal since 2003. Armenal is the second largest foil mill among Rusal's subsidiaries, producing about 25 thousand tons of foil per year.

9 The text and details of the judgment of the court can be found http://eur-lex.europa.eu/LexUriServ/ LexUriServ.do?uri=CELEX:62009TJ0512:EN:HTML.

10 Alcomet PLC of Bulgaria and Symetal Aluminum Foil Industry SA of Greece were identified as domestic producers of the subject aluminum foil and were included in $\mathrm{AD}$ investigation to determine the dumping margins (OJ 2009 L 94, p. 17).

11 In 2012, the EU initiated an anti-dumping investigation with regard to imports of low-weight aluminum foil from China and imposed anti-dumping duties on this kind of aluminum foil originating in China as well. 
between 1980 and 1994; imports from affected countries drop by about $50 \%$, whereas imports from unaffected countries rise by $40-60 \%$. On the contrary, Lasagni (2000) and Konings et al. (2001) find limited trade diversion effect from EU AD actions between 1985 and 1990.

Bown and Crowley (2006) examine the effect of US AD duties on Japanese exports over the period of 1992-2001 and find significant trade deflection and trade depression effects in the EU market, in addition to the trade destruction and trade diversion effects. Baylis and Perloff (2010) document trade diversion involving a related product: the US AD investigation of fresh tomatoes from Mexico that resulted in a suspension agreement prompted a significant increase in Mexico's exports of tomato paste to the US. ${ }^{12}$

Despite the rich body of research on the trade effects of AD duties, the EU antidumping action regarding aluminum foil is unique and deserves a separate examination. First, it affects countries of vastly different stages of development and export capacity. On one hand, China, the manufacturing powerhouse of the world, is a frequent target of EU anti-dumping investigations (about 50 out of $120 \mathrm{AD}$ investigations initiated by the EU between 2006 and 2012 targeted China). On the other hand, Armenia, a small landlocked country with the least diversified export basket with aluminum foil representing about $10 \%$ of its total exports, has never been subject to any anti-dumping investigation. Armenia exports less than $\$ 100$ million annually to the US, and aluminum foil makes up much of this (about $85 \%$ ). In contrast, Brazil and China export a diverse set of products valued in the billions to the US. Despite these differences, these countries represent the top three source countries of aluminum foil for the US as of 2012 (see Table 2). Second, the trade effects may capture some intrafirm decisions of multinational corporations as they respond to $\mathrm{AD}$ duties; in our case, the Armenian producer of aluminum foil is the subsidiary of Russian company Rusal which is not directly affected by the EU AD duties. This case illustrates the inability of anti-dumping duties to generate the desired effects in the presence of multinational corporations with subsidiaries located in different countries when the duties target only one of the countries. Finally, this paper contributes to the existing literature by examining the trade effects of a single antidumping action at a very disaggregated level (8-digit product classification) within a narrowly defined industry (aluminum sheet, plate, and foil manufacturing), while previous studies use multiple $\mathrm{AD}$ actions initiated over a certain period to examine the effect of a single shock - an initiation of AD investigation - on trade flows.

12 According to the suspension agreement, Mexico voluntarily limited its exports and, in return, the US suspended the anti-dumping case and removed the anti-dumping duties. 


\section{Empirical analysis}

\subsection{Data}

In order to examine the effect of EU anti-dumping duties on EU and US imports, we construct a panel of all countries exporting aluminum products to the EU or US at the CN or HS 8-digit level for the period from 2006 through 2012. To identify these products, we first identify HS 6-digit product categories that correspond to the aluminum sheet, plate, and foil manufacturing industry, defined according to the North American Industry Classification System (NAICS) as a 6-digit industry (331315), and then use all HS or CN 8-digit products within HS 6-digit categories for each country. ${ }^{13}$ The US imported 11 products within this industry, among which only one was subject to the EU anti-dumping duty in 2009 (HS 8-digit product 7607.11.60). ${ }^{14}$ The EU imported 15 products within this industry, of which one was subject to AD duty (CN 8-digit product 7607.11.10). As discussed above, in the midst of $\mathrm{AD}$ investigation the EU product classification was changed to distinguish between consumer rolls or rolls below $10 \mathrm{~kg}$ (CN 8-digit product 7607.11.11) and jumbo reels or reels in excess of $10 \mathrm{~kg}$ of aluminum foil (CN 8-digit product 7607.11.19) with only the latter being the subject of AD investigation. Since data on imports of these two products are not available prior to 2009 , the value of EU imports recorded under these two separate product lines after 2009 is combined for use in the empirical investigation. Data on annual US and EU imports of all aluminum products from all countries are obtained from the US International Trade Commission and Eurostat, respectively. ${ }^{15}$

Table 1 provides summary statistics for the EU imports of aluminum foil between 2006 and 2012 with the top panel reporting values for low-weight and high-weight aluminum foil rolls separately starting in 2009 and the bottom panel showing the combined value of these two products, which is used in the empirical analysis. The bottom panel also reports the total import value of other aluminum products imported by the EU. There are several interesting observations. First, China is the largest supplier of aluminum foil to the EU market; both in 2007 and 2008 close to $50 \%$ of imports came from China. Second, after the split of the product

13 Appendix Table A1 lists product codes of all aluminum products within the aluminum sheet, plate, and foil manufacturing industry imported by the US and the EU between 2006 and 2012 .

14 The product subject to the EU anti-dumping duty is described as "Aluminum foil of a thickness of not less than $0.008 \mathrm{~mm}$ and not more than $0.018 \mathrm{~mm}$, not backed, not further worked than rolled, in reels of a width not exceeding $650 \mathrm{~mm}$ ' in the EU Tariff Code. The US Tariff Code has two separate codes for aluminum foil that partially overlap in their thickness with that in the EU Tariff Code - aluminum foil of thickness below $0.01 \mathrm{~mm}$ and of thickness between 0.01 and $0.15 \mathrm{~mm}$. The latter largely overlaps with the range of thickness identified in the EU Tariff Code and subject to the anti-dumping duty. Thus, the comparable HS 8-digit product used in the analysis is "Aluminum foil of a thickness exceeding $0.01 \mathrm{~mm}$ and not exceeding $0.15 \mathrm{~mm}$, not backed, rolled but not further worked" in the US tariff code (7607.11.60).

15 For the EU data, any imports valued below 2,000 euros are dropped; a similar truncation $(\$ 2,000)$ is applied to the US data by the Census Bureau. 
Do Anti-dumping Duties Still Matter? The Curious Case of Aluminum Foil 565

Table 1. EU imports of aluminum foil (in million euros)

\begin{tabular}{|c|c|c|c|c|c|c|}
\hline Year & Armenia & Brazil & China & Russia & ROW & Total \\
\hline & \multicolumn{6}{|c|}{ Aluminum foil (CN 7607.11.10) } \\
\hline 2006 & 0.2 & 21 & 23 & 32 & 87 & 164 \\
\hline 2007 & 15 & 23 & 113 & 30 & 71 & 252 \\
\hline \multirow[t]{2}{*}{2008} & 6 & 14 & 94 & 17 & 42 & 173 \\
\hline & \multicolumn{6}{|c|}{ Under $10 \mathrm{~kg}$ (CN 7607.11.11) } \\
\hline 2009 & 0 & 1.4 & 16 & 0.6 & 23 & 41 \\
\hline 2010 & 0 & 0.05 & 21 & 0.5 & 18 & 40 \\
\hline 2011 & 0.02 & 0 & 45 & 0.5 & 21 & 66 \\
\hline \multirow[t]{2}{*}{2012} & 0 & 0 & 26 & 0 & 13 & 39 \\
\hline & \multicolumn{6}{|c|}{ Over $10 \mathrm{~kg}$ (CN 7607.11.19) - target of AD action } \\
\hline 2009 & 0.7 & 4.6 & 21 & 33 & 19 & 79 \\
\hline 2010 & 1.5 & 0 & 39 & 62 & 34 & 137 \\
\hline 2011 & 1 & 0 & 79 & 63 & 45 & 189 \\
\hline 2012 & 2 & 0.1 & 65 & 70 & 56 & 193 \\
\hline
\end{tabular}

\begin{tabular}{|c|c|c|c|c|c|c|c|}
\hline \multirow[b]{2}{*}{ Year } & \multicolumn{6}{|c|}{ Aluminum foil (combined) } & \multirow{2}{*}{$\begin{array}{l}\text { Other aluminum products } \\
\text { Total }\end{array}$} \\
\hline & Armenia & Brazil & China & Russia & ROW & Total & \\
\hline 2006 & 0.2 & 21.3 & 23 & 32 & 87 & 164 & 1,906 \\
\hline 2007 & 14.9 & 23.0 & 113 & 30 & 71 & 252 & 2,267 \\
\hline 2008 & 5.9 & 13.9 & 94 & 17 & 42 & 173 & 2,107 \\
\hline 2009 & 0.7 & 6.0 & 37 & 34 & 42 & 120 & 1,365 \\
\hline 2010 & 1.5 & 0.0 & 60 & 63 & 52 & 176 & 1,959 \\
\hline 2011 & 1.0 & 0.0 & 124 & 64 & 66 & 255 & 2,609 \\
\hline 2012 & 2.0 & 0.1 & 92 & 70 & 69 & 232 & 2,333 \\
\hline
\end{tabular}

Notes: Computed from Eurostat trade database.

code in 2009 and the imposition of the anti-dumping duty, Armenia and Brazil which exported predominantly jumbo reels to the EU saw a dramatic decrease in their exports of aluminum foil to the EU which were barely visible on the EU market for aluminum foil by 2012. In contrast, after China's exports plummeted in 2009, they recovered fully and surpassed the pre-recession level by 2011; this was driven by an increase in exports of both jumbo reels and consumer rolls, as predicted by the EU downstream industry producers. The decline in Chinese exports of aluminum foil in 2012 can be attributed to the new AD duties on low-weight aluminum foil. Third, Russia's exports of aluminum foil more than doubled over the sample period, surpassing in growth rates that of the rest of the world. Total EU import demand for aluminum foil and other aluminum products remained relatively stable, except for the sharp decline in 2009 most likely associated with the great recession.

Table 2 provides summary statistics on the value of US imports of aluminum products from various countries over the years 2006 through 2012. More specifically, it shows US imports from Armenia, Brazil, China, Russia, as well as those from the 
Table 2. US imports of aluminum products (in million dollars)

\begin{tabular}{|c|c|c|c|c|c|c|c|}
\hline \multirow[b]{2}{*}{ Year } & \multicolumn{6}{|c|}{ Aluminum foil (HS 7607.11.60) } & \multirow{2}{*}{$\begin{array}{c}\text { Other aluminum products } \\
\text { Total }\end{array}$} \\
\hline & Armenia & Brazil & China & Russia & ROW & Total & \\
\hline 2006 & 0 & 3 & 25 & 42 & 119 & 189 & 3,327 \\
\hline 2007 & 2 & 1 & 22 & 43 & 109 & 177 & 3,167 \\
\hline 2008 & 12 & 9 & 35 & 64 & 86 & 206 & 2,838 \\
\hline 2009 & 62 & 14 & 12 & 22 & 28 & 138 & 1,577 \\
\hline 2010 & 65 & 48 & 34 & 1 & 34 & 182 & 2,288 \\
\hline 2011 & 78 & 52 & 70 & 1 & 40 & 241 & 2,741 \\
\hline 2012 & 77 & 39 & 61 & 0 & 42 & 219 & 2,427 \\
\hline
\end{tabular}

Notes: Computed from USITC database.

rest of the world, for aluminum foil and the combined sum of aluminum products other than aluminum foil. Total US imports of aluminum foil exhibited a slight growth over time, with a sizable decline in 2009 during the great trade collapse. A sharp rise is observed in imports from China and Brazil after 2009; 2008 for Armenia. At the same time, imports from Russia dropped sharply in 2009, and virtually disappeared by 2010 . The US imports from the rest of the world declined sharply in 2009 due to depressed US demand in the midst of the great recession and ensuing great trade collapse. They picked up slightly after 2009, but stayed well below the pre-recession levels and contributed little to the overall growth in imports of aluminum foil after 2009.

\subsection{Estimation strategy}

The trends presented above show that EU imports of aluminum foil from unaffected countries and US imports from the countries subject to EU antidumping duties increased dramatically after the imposition of AD duties, while there was a marked decline in EU imports from affected countries and US imports from unaffected countries. Econometric evidence is next presented to better gauge the size of the impact of EU AD protection - trade deflection, depression, diversion and destruction - depicted in Tables 1-2 and Figures 1-2, controlling for trends in imports of aluminum foil from other countries and imports of other aluminum products.

The effect of the EU's AD action on imports into the EU and US is estimated using a triple difference specification. There are other countries that export aluminum foil that are not directly impacted by the EU duties, including most prominently Russia. Also exports of all aluminum products, and not just aluminum foil, may be impacted by shocks that may have coincided with the EU decree applied to aluminum foil. Imports of all other aluminum products from all countries are examined as a control for imports of aluminum foil from the affected countries. Accordingly, the 
empirical analysis hinges upon a triple-difference regression specification that examines whether imports decline from countries subject to AD duty (first difference) after the imposition of $\mathrm{AD}$ duties (second difference) compared to other products in aluminum sheet, plate, and foil manufacturing (third difference):

$$
\operatorname{lnImports}_{c p t}=\alpha+\sum_{c} \beta_{c} \text { Country }_{c} \times \text { Foil }_{p} \times A D_{t}+F E+\epsilon_{c p t}
$$

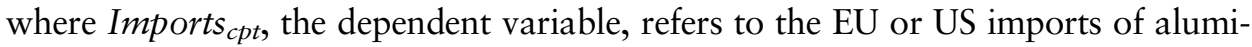
num product $p$ (at the HS or CN 8-digit level) from country $c$ in year $t$. The variable Country $_{c}$ is a time-invariant dummy that takes the value of 1 for countries Armenia, Brazil, China, and Russia, and 0 otherwise. The variable Foil $p$ is a time-invariant dummy that takes the value of 1 if the product is aluminum foil (HS 8-digit code 7607.11.60 or $\mathrm{CN}$ 8-digit code 7607.11.10) and 0 otherwise. The variable $A D_{t}$ is a dummy that switches from 0 to 1 for all countries and products in 2009 when the EU implemented the anti-dumping duties on aluminum foil. The estimated coefficients (aside from the fixed effects) on the four triple-interaction terms, $\beta$ s, measure the trade deflection or destruction effect of EU anti-dumping duties for Armenia, Brazil, and China, and the trade depression or diversion effect for Russia. The empirical specification allows for the inclusion of a rich set of fixed effects. Our preferred specification includes a full set of interactive fixed effects - country-product, countryyear and product-year - to allow for heterogeneity in the level of imports of any product from any country, the overall imports from any country in any year, and the overall imports of any product in any year.

As an alternative to measuring the response on the level of imports, the impact of EU anti-dumping duties on market shares of affected countries is also examined. Equation (1) is re-estimated by replacing the dependent variable with the share of a given country in total imports of a given product into the EU or US market. And as a further robustness check, the value of imports in equation (1) is replaced with the quantity of imports.

\section{Results}

Table 3 reports the first set of empirical results for the impact of EU AD measures on EU and US imports over the 2006-2012 period and presents evidence of trade destruction, trade diversion, trade deflection, and trade depression. Estimated coefficients on imports from each of the four countries are reported with robust standard errors in parentheses. All regressions include a full set of interactive fixed effects.

Column 1 presents estimates from examining the response of EU imports from affected and unaffected countries. Here the estimated coefficients for Armenia, Brazil, and China provide potential evidence of trade destruction, and for Russia, evidence of trade diversion. The estimates suggest statistically and economically significant trade destruction for Armenia and Brazil (implying a 94\% drop in 
Table 3. The effect of EU anti-dumping duties on EU and US imports: triple difference

\begin{tabular}{|c|c|c|c|c|}
\hline \multirow[b]{2}{*}{ Variables } & \multicolumn{2}{|c|}{ Imports } & \multicolumn{2}{|c|}{ Share } \\
\hline & EU (1) & US (2) & EU (3) & US (4) \\
\hline \multicolumn{5}{|c|}{ Country $\times \mathrm{AD} \times$ foil } \\
\hline Armenia & $\begin{array}{c}-2.845 * * * \\
(0.912)\end{array}$ & $\begin{array}{c}2.593 * * * \\
(0.683)\end{array}$ & $\begin{array}{c}-4.220 * * * \\
(1.063)\end{array}$ & $\begin{array}{c}30.87 * * * \\
(1.824)\end{array}$ \\
\hline Brazil & $\begin{array}{c}-2.774 * * \\
(1.370)\end{array}$ & $\begin{array}{c}2.148 * * * \\
(0.778)\end{array}$ & $\begin{array}{c}-5.725 * * \\
(2.260)\end{array}$ & $\begin{array}{c}17.67 * * * \\
(3.909)\end{array}$ \\
\hline China & $\begin{array}{l}-0.432 \\
(0.337)\end{array}$ & $\begin{array}{l}-0.199 \\
(0.494)\end{array}$ & $\begin{array}{l}-8.298 \\
(9.949)\end{array}$ & $\begin{array}{l}-2.750 \\
(4.660)\end{array}$ \\
\hline Russia & $\begin{array}{c}2.219 * * * \\
(0.437)\end{array}$ & $\begin{array}{c}-3.854 * * \\
(1.827)\end{array}$ & $\begin{array}{c}19.41 * * * \\
(2.985)\end{array}$ & $\begin{array}{c}-19.54 * * * \\
(4.893)\end{array}$ \\
\hline \multicolumn{5}{|c|}{ Marginal effect } \\
\hline Armenia & $-94 \% * * *$ & $1,237 \% * * *$ & & \\
\hline Brazil & $-94 \% * *$ & $757 \% * * *$ & & \\
\hline China & $-35 \%$ & $-18 \%$ & & \\
\hline Russia & $820 \% * * *$ & $-98 \% * *$ & & \\
\hline Observations & 2,310 & 1,971 & 2,310 & 1,971 \\
\hline R-squared & 0.918 & 0.885 & 0.860 & 0.843 \\
\hline
\end{tabular}

Notes: The dependent variable in all regressions is log US or EU imports or share in imports. All regressions include a full set of interactive fixed effects: country-product, country-year, and product-year. Robust standard errors in parentheses. The marginal effects throughout this paper are calculated as $\exp (\beta)-1$ if the dependent variable is lnImports. $* * * * *$, and $*$ indicate significance at the $1 \%, 5 \%$, and $10 \%$ level, respectively.

imports from both countries into the EU), while point estimates for China are negative but imprecisely measured. One possible explanation for why we find no statistically significant trade destruction effect for China is that, as discussed earlier, the EU imports data could potentially mismeasure the effects of $\mathrm{AD}$ action because of the change in the classification of aluminum foil and the need to combine the import values of jumbo reels and consumer rolls. This is likely to underestimate the trade destruction effect for China since China produces and exports both products to the EU, as shown in Table 1. Turning to the estimated coefficient for Russia, the results provide statistically significant evidence of trade diversion - the EU AD action led to an increase in imports from a country not directly affected by AD duty; Russia's exports to the EU increased by more than $800 \%$ after 2009 .

Column 2 explores the impact of EU AD action on imports from the same four countries into the US. The US imports of aluminum foil from Armenia and Brazil increased dramatically after the imposition of EU anti-dumping duties, which mirrors the trade destruction results for the EU reported in Column 1. The positive and statistically significant coefficient estimates for Armenia and Brazil are indicative of sizable trade deflection. In particular, our estimates imply that Brazil's 
exports of aluminum foil to the US increased by more than $750 \%$ after the imposition of EU AD duties, while Armenia's exports increased by over 1,000\%! The latter figure is not surprising as Armenia exported very small amounts of aluminum foil to the US prior to 2009. The imprecisely estimated coefficient on China mirrors the same finding for the EU market: the EU AD duty seems to have not altered much the US sourcing patterns from China. The estimated coefficient for Russia provides evidence of trade depression whereby countries not directly affected by the EU AD action may divert their exports from their existing export destinations, in this case the US, to the EU to fill the void in the EU market. The implied drop in Russian exports of aluminum foil to the US is about $98 \%$. This corresponds to the trade diversion effect found in Column 1 when Russia's exports to the EU market increased, and is consistent with the basic tabulations in Table 2. ${ }^{16}$

Qualitatively similar results are gleaned from Columns 3 and 4 which report the impact of EU AD duties on the EU and US import shares of countries directly and indirectly affected by the duties. Armenia became the top source of aluminum foil for the US with its import share increasing on average by 31 percentage points after the imposition of EU duties (Column 4). The import share of Brazil also increased, by 18 percentage points, whereas Russia's import share declined on average by 20 percentage points. In the EU market, Russia's import share increased by 19 percentage points, while Armenia's and Brazil's import shares declined by 4 and 6 percentage points, respectively. Once again, the estimates for China are imprecisely estimated for reasons explained above.

As a check on the robustness of results from the triple difference specification, the sample is restricted to imports of aluminum foil only and a standard difference-indifferences specification is estimated. This reduces the sample to 199 observations for the EU and 187 for the US. The regressions here include country and year fixed effects, with results reported in Table 4. This estimator identifies the EU AD duty effect solely from the relative change in imports of aluminum foil from targeted

16 As discussed in footnote 14, the product subject to the EU anti-dumping duty (aluminum foil of thickness between 0.008 and $0.018 \mathrm{~mm}$ ) does not have an exact counterpart in the US Tariff Code, which has two codes for aluminum foil partially overlapping in its thickness to the EU product - below $0.01 \mathrm{~mm}$, and between 0.01 and $0.15 \mathrm{~mm}$. The analysis so far used the aluminum foil of thickness between 0.01 and $0.15 \mathrm{~mm}$ as an affected product for the US market. As a robustness check, we also run the regressions assuming aluminum foil of thickness both below $0.01 \mathrm{~mm}$ and between 0.01 and $0.15 \mathrm{~mm}$ as affected products for the US, with the results reported in Appendix Table A2. Columns 1 and 3 replicate the results from Table 3 Columns 3 and 4 where only one product is assumed to be affected by the EU antidumping duty. Columns 2 and 4 assume two products are affected. Focusing on import value regression, the results show a similar trade deflection effect for Armenia, which is not surprising because Armenia predominantly exports aluminum foil of thickness between 0.01 and $0.15 \mathrm{~mm}$ to the US. However, the trade deflection and trade depression effects becomes statistically insignificant for Brazil, China, and Russia, which along with earlier results suggests that much of the impact of the EU antidumping duties falls on aluminum foil of thickness between 0.01 and $0.15 \mathrm{~mm}$, and not on that of thickness below $0.01 \mathrm{~mm}$. Hence, the rest of the analysis uses aluminum foil of thickness between 0.01 and $0.15 \mathrm{~mm}$ as an affected product for the US. 
Table 4. The effect of EU anti-dumping duties: standard difference-in-differences

\begin{tabular}{|c|c|c|c|c|}
\hline \multirow[b]{2}{*}{ Variables } & \multicolumn{2}{|c|}{ Imports } & \multicolumn{2}{|c|}{ Share } \\
\hline & EU (1) & US (2) & EU (3) & US (4) \\
\hline \multicolumn{5}{|l|}{ Country $\times A D$} \\
\hline Armenia & $\begin{array}{l}-0.353 \\
(1.338)\end{array}$ & $\begin{array}{c}4.483^{* * *} \\
(1.093)\end{array}$ & $\begin{array}{l}-2.253 \\
(1.655)\end{array}$ & $\begin{array}{c}36.65^{* * *} \\
(3.322)\end{array}$ \\
\hline Brazil & $\begin{array}{c}-3.677^{* *} \\
(1.519)\end{array}$ & $\begin{array}{c}3.046 * * * \\
(0.578)\end{array}$ & $\begin{array}{c}-8.122 * * * \\
(2.193)\end{array}$ & $\begin{array}{c}18.44 * * * \\
(3.820)\end{array}$ \\
\hline China & $\begin{array}{c}0.437 \\
(0.512)\end{array}$ & $\begin{array}{c}1.017 * * * \\
(0.389)\end{array}$ & $\begin{array}{c}0.618 \\
(12.37)\end{array}$ & $\begin{array}{l}8.993 * \\
(5.075)\end{array}$ \\
\hline Russia & $\begin{array}{c}1.096 * * * \\
(0.324)\end{array}$ & $\begin{array}{c}-3.996^{* * *} \\
(1.943)\end{array}$ & $\begin{array}{c}16.18 * * * \\
(3.636)\end{array}$ & $\begin{array}{c}-19.80 * * * \\
(4.923)\end{array}$ \\
\hline \multicolumn{5}{|l|}{ Marginal effect } \\
\hline Armenia & $-30 \%$ & $8,750 \% * * *$ & & \\
\hline Brazil & $-97 \% * *$ & $2,003 \% * * *$ & & \\
\hline China & $55 \%$ & $176 \% * * *$ & & \\
\hline Russia & $199 \% * * *$ & $-98 \% * *$ & & \\
\hline Observations & 199 & 187 & 199 & 187 \\
\hline R-squared & 0.872 & 0.824 & 0.892 & 0.807 \\
\hline
\end{tabular}

Notes: The sample is limited to imports of aluminum foil only. The dependent variable in all regressions is $\log$ US or EU imports or share in imports. All regressions include country and year fixed effects. Robust standard errors in parentheses. $* * * * *$, and $*$ indicate significance at the $1 \%, 5 \%$, and $10 \%$ level, respectively.

versus non-target countries. The results broadly mirror the earlier ones from triple difference estimation but with marked differences for imports value regressions. In particular, the estimates of trade deflection in the US market are much larger and statistically significant for all three countries targeted by the EU AD duty. Thus, the effect of $\mathrm{EU} \mathrm{AD}$ duty is overestimated as the estimates fail to take into account the overall increase in US imports for all categories of aluminum products from 2009 to 2012. The estimates for Armenia in the EU market are imprecisely measured in this specification, while the estimates for Russia (trade diversion effect) are now smaller in magnitude. These changes in estimates highlight the importance of controlling for trade in non-foil aluminum products.

The results reported so far examine the impact of the EU AD duties on values of imports into the EU and US. This effect is further disentangled into the impact on the volume of imports and unit values. Table 5 replicates the results from Table 3 replacing the dependent variable with log quantity of imports and log unit value. The trade destruction and trade diversion effects on the EU market, as well as trade deflection and trade depression effects on the US market remain statistically and economically significant in real terms; the quantity of imports from Armenia to the EU drops by $95 \%$ and to the US rises by more than $2,300 \%$, the quantity of imports from Russia to the EU rises by more than $1,000 \%$ and to the US falls by $97 \%$, 
Table 5. The effect of EU anti-dumping duties on volume of EU and US imports and unit values

\begin{tabular}{|c|c|c|c|c|}
\hline \multirow[b]{2}{*}{ Variables } & \multicolumn{2}{|c|}{ Quantity } & \multicolumn{2}{|c|}{ Unit value } \\
\hline & $\mathrm{EU}(1)$ & US (2) & $\mathrm{EU}(3)$ & US (4) \\
\hline \multicolumn{5}{|c|}{ Country $\times \mathrm{AD} \times$ oil } \\
\hline Armenia & $\begin{array}{c}-3.027 * * * \\
(0.953)\end{array}$ & $\begin{array}{c}3.184 * * * \\
(0.782)\end{array}$ & $\begin{array}{l}0.226 * \\
(0.134)\end{array}$ & $\begin{array}{c}-0.613 * \\
(0.357)\end{array}$ \\
\hline Brazil & $\begin{array}{l}-2.067 \\
(1.345)\end{array}$ & $\begin{array}{c}2.073 * * \\
(0.954)\end{array}$ & $\begin{array}{l}-0.529 \\
(0.395)\end{array}$ & $\begin{array}{l}0.0738 \\
(0.380)\end{array}$ \\
\hline China & $\begin{array}{l}-0.462 \\
(0.414)\end{array}$ & $\begin{array}{l}-0.117 \\
(0.607)\end{array}$ & $\begin{array}{l}0.0179 \\
(0.129)\end{array}$ & $\begin{array}{c}-0.0928 \\
(0.209)\end{array}$ \\
\hline Russia & $\begin{array}{c}2.430 * * * \\
(0.521)\end{array}$ & $\begin{array}{c}-3.628 * \\
(1.855)\end{array}$ & $\begin{array}{l}-0.230 \\
(0.153)\end{array}$ & $\begin{array}{l}-0.240 \\
(0.254)\end{array}$ \\
\hline \multicolumn{5}{|l|}{ Marginal effect } \\
\hline Armenia & $-95 \% * * *$ & $2,314 \% * * *$ & $25 \% *$ & $-46 \% *$ \\
\hline Brazil & $-87 \%$ & $695 \% *$ & $-41 \%$ & $8 \%$ \\
\hline China & $-37 \%$ & $-11 \%$ & $2 \%$ & $-9 \%$ \\
\hline Russia & $1,036 \% * * *$ & $-97 \% *$ & $-21 \%$ & $-21 \%$ \\
\hline Observations & 2,269 & 1,971 & 2,269 & 1,971 \\
\hline R-squared & 0.907 & 0.863 & 0.786 & 0.697 \\
\hline
\end{tabular}

Notes: The dependent variable in all regressions is the US or EU log quantity of imports or log unit value. All regressions include a full set of interactive fixed effects: country-product, country-year, and product-year. Robust standard errors in parentheses. $* * * * *$, and $*$ indicate significance at the $1 \%$, $5 \%$, and $10 \%$ level, respectively.

and, finally, the quantity of imports from Brazil to the US increases by about $700 \%$. These results confirm that the EU AD action has resulted in significant trade destruction, diversion, deflection, and depression effects in both nominal and real terms.

Furthermore, the results in Columns 3 and 4 in Table 5 reveal virtually no price effects from the EU AD action, except for unit values of aluminum foil imported from Armenia. The EU AD duty promoted a $25 \%$ increase in the unit value of aluminum foil imported into the EU market and a $46 \%$ decline in the unit value of the same product imported into the US market. The former seems to suggest that the Armenian producer may have strategically increased the price of the exported aluminum foil to the EU to head off any further anti-dumping investigation.

\section{Conclusion}

This paper explores the consequences of the EU anti-dumping duties levied on aluminum foil imports from Armenia, Brazil, and China in 2009. In the aftermath of the duties, exports from these countries to the EU declined considerably. More interestingly, this decline was accompanied by a simultaneous increase in exports from these countries to the US suggesting substantial trade deflection. Armenia 
represents an interesting case where exports to the US increased dramatically, reflecting not only trade deflection but also possible intra-company adjustments as a consequence of the imposed duties; the Armenian producer of aluminum foil is a subsidiary of the Russian company Rusal. The results can be used to speculate that in response to EU AD action, Rusal may have channeled the exports of aluminum foil produced in its Russian plants to the EU market, meanwhile redirecting the exports of aluminum foil produced in its Armenian plant from the EU to the US market. These findings suggest that in the presence of multinational corporations, the intended outcome of anti-dumping duties may be difficult to achieve given that producers of the same product may own plants in multiple countries and hence could strategically switch destination markets for their exports originating in subject and non-subject countries. In such instances, the trade diversion becomes an intra-firm matter and is likelier to occur.

\section{References}

Baylis, K. and J. M. Perloff (2010), 'Trade Diversion from Tomato Suspension Agreements', Canadian Journal of Economics, 43(1): 127-151.

Blonigen, B. A. and T. J. Prusa (2016), 'Dumping and Antidumping Duties', Handbook of Commercial Policy, 1: 107-159.

Bown, C. P. and M. A. Crowley (2006), 'Policy Externalities: How US Antidumping Affects Japanese Exports to the EU', European Journal of Political Economy, 22(3): 696-714.

Konings, J., H. Vandenbussche, and L. Springael (2001), 'Import Diversion under European Antidumping Policy', Journal of Industry, Competition and Trade, 1(3): 283-299.

Lasagni, A. (2000), 'Does Country-targeted Anti-dumping Policy by the EU Create Trade Diversion?', Journal of World Trade, 34(4): 137-160.

Official Journal of the European Union, various publications.

Prusa, T. J. (1997), 'The Trade Effects of US Antidumping Actions', in R. Feenstra (ed.), The Effects of US Trade Protection and Promotion Policies, Chicago: University of Chicago Press.

— (2001), 'On the Spread and Impact of Antidumping', Canadian Journal of Economics, 34(3): 591-611. 
Do Anti-dumping Duties Still Matter? The Curious Case of Aluminum Foil 573

\section{Appendix}

Table A1. Products within NAICS industry 331315 (aluminum sheet, plate, and foil manufacturing)

List of US HS8 products

List of EU CN8 products

76061130

76061110

76061160

76061191

76061230

76061193

76061260

76061199

76069130

76061210

76069160

76061220

76069230

76061250

76069260

76061291

76071130

76061292

76071160

76061293

76071190

76061299

76069100

76069200

76071110

76071190

Notes: The US HS 8-digit code for the affected aluminum foil is 7607.11.60; the EU CN 8-digit code was 7607.11.10 at the time of initiation of investigation. The latter was split into two separate codes in January 2009; the values reported under two separate codes are combined in the paper to allow for the estimation.

Table A2. Robustness check: the effect of EU anti-dumping duties on US imports

\begin{tabular}{|c|c|c|c|c|}
\hline \multirow[b]{2}{*}{ Variables } & \multicolumn{2}{|c|}{ Imports } & \multicolumn{2}{|c|}{ Share } \\
\hline & $\begin{array}{l}\text { One affected } \\
\text { product (1) }\end{array}$ & $\begin{array}{l}\text { Two affected } \\
\text { products (2) }\end{array}$ & $\begin{array}{l}\text { One affected } \\
\text { product (3) }\end{array}$ & $\begin{array}{l}\text { Two affected } \\
\text { products }(4)\end{array}$ \\
\hline \multicolumn{5}{|c|}{ Country $\times \mathrm{AD} \times$ foil } \\
\hline Armenia & $\begin{array}{c}2.593 * * * \\
(0.683)\end{array}$ & $\begin{array}{c}2.723 * * * \\
(0.704)\end{array}$ & $\begin{array}{c}30.87^{* * * *} \\
(1.824)\end{array}$ & $\begin{array}{c}31.67^{* * *} \\
(1.927)\end{array}$ \\
\hline Brazil & $\begin{array}{c}2.148 * * * \\
(0.778)\end{array}$ & $\begin{array}{l}1.072 \\
(0.858)\end{array}$ & $\begin{array}{c}17.67 * * * \\
(3.909)\end{array}$ & $\begin{array}{l}8.346^{* *} \\
(4.143)\end{array}$ \\
\hline China & $\begin{array}{l}-0.199 \\
(0.494)\end{array}$ & $\begin{array}{c}0.495 \\
(0.475)\end{array}$ & $\begin{array}{l}-2.750 \\
(4.660)\end{array}$ & $\begin{array}{l}13.31 * \\
(7.038)\end{array}$ \\
\hline Russia & $\begin{array}{c}-3.854 * * \\
(1.827)\end{array}$ & $\begin{array}{l}-0.597 \\
(1.731)\end{array}$ & $\begin{array}{c}-19.54 * * * \\
(4.893)\end{array}$ & $\begin{array}{c}-10.16^{* *} \\
(4.985)\end{array}$ \\
\hline $\begin{array}{l}\text { Marginal e } \\
\text { Armenia }\end{array}$ & $1,237 \% * * *$ & $1,422 \% * * *$ & & \\
\hline
\end{tabular}


Table A2. (Cont.)

\begin{tabular}{lcclll}
\hline \hline & \multicolumn{2}{c}{ Imports } & & \multicolumn{2}{c}{ Share } \\
\cline { 2 - 3 } \cline { 5 - 6 } Variables & $\begin{array}{l}\text { One affected } \\
\text { product (1) }\end{array}$ & $\begin{array}{c}\text { Two affected } \\
\text { products (2) }\end{array}$ & & $\begin{array}{l}\text { One affected } \\
\text { product (3) }\end{array}$ & $\begin{array}{l}\text { Two affected } \\
\text { products (4) }\end{array}$ \\
\hline Brazil & $757 \% * * *$ & $192 \%$ & & & \\
China & $-18 \%$ & $64 \%$ & & & 1,971 \\
Russia & $-98 \% * *$ & $-45 \%$ & & 1,971 & 0.842 \\
Observations & 1,971 & 1,971 & & 0.843 & \\
R-squared & 0.885 & 0.884 & & 0.89 & \\
\hline
\end{tabular}

Notes: The dependent variable in all regressions is log US imports or share in imports. All regressions include a full set of interactive fixed effects: country-product, country-year, and product-year. Robust standard errors in parentheses. $* * * *$, and $*$ indicate significance at the $1 \%, 5 \%$, and $10 \%$ level, respectively. Columns 1 and 3 repeat the baseline estimates from Table 3, Columns 2 and 4, where the affected product is aluminum foil of a thickness $0.01-0.15 \mathrm{~mm}$. Columns 2 and 4 report the results from regressions where two products are assumed to be affected by the EU AD duty - aluminum foil of a thickness below $0.01 \mathrm{~mm}$ and of a thickness $0.01-0.15 \mathrm{~mm}$. 